\title{
ПРОФЕССИОНАЛЬНОЕ САМООПРЕДЕЛЕНИЕ КАК ПСИХОГЕНЕТИЧЕСКИЙ ВЫБОР ПРОФЕССИИ НА ОСНОВАНИИ АНАЛИЗА ГЕНЕТИЧЕСКОГО ДРЕВА И ОЦЕНКИ ВНУТРЕННИХ РЕСУРСОВ СУБЪЕКТА
}

\section{Гордиенко Н.В., Смирнова К.А.}

ФГБОУ ВО «Пятигорский Государственный Университет»,

г. Пятигорск, Ставропольский край, Российская Федерация

В статье рассмотрен феномен психогенетического выбора профессии на основании анализа генетического древа и оченки внутренних ресурсов субъекта, подробно рассмотрены вопросы взаимосвязи между предопреде-ленностью профессионального выбора на основании генетического фактора и формированием личности в развитии, с учетом влияния на данный процесс условий среды, других лии (родителей, преподавателей, сверстников).

В работе использованы статьи известных российских и зарубежных ученых, имеющих по данной теме результаты многолетних исследований и наблюдений.

Ключевые слова: профессия; самоопределение; генетическое древо как внутренние ресурсы; субъект.

\section{PROFESSIONAL SELF-DETERMINATION AS A PSYCHOGENETIC CHOICE OF PROFESSIONALISM BASED ON THE ANALYSIS OF THE GENETIC TREE AND THE ASSESSMENT OF THE INTERNAL RESOURCES OF THE SUBJECT}

\section{Gordienko N.V., Smirnova K.A.}

Pyatigorsk State University,

Pyatigorsk, Stavropol region, Russian Federation

The article considers the phenomenon of psychogenetic career choice based on the analysis of the genetic tree and the assessment of the internal resources of the subject, the issues of interrelation between the 
predetermination of professional choice on the basis of the genetic factor and the formation of personality in development, taking into account the influence of environmental conditions on this process, other persons (parents, teachers, peers) are considered in detail.

The article contains articles by well-known Russian and foreign scientists who have the results of many years of research and observations on this topic.

Keywords: profession; self-determination; genetic tree as internal resources; subject.

Вопрос о подготовке подрастающего поколения к трудовой деятельности является очень важным с давних пор. В настоящий период, когда в России происходят сильнейшие общественно-экономические трансформации, когда проблема мирового экономического кризиса докатилась и до нас, вопрос о выборе молодёжью своего жизненного пути и приобретения профессии встает особенно остро.

В первую очередь проблема профессионального самоопределения остро встает перед старшеклассниками, для которых выбор своего последующего образования и получения профессии обращается в объективную реальность.

Актуальность проблемы профессионального самоопределения старших школьников особенно возрастает в условиях присоединения и участия России в Болонском процессе. Как показывают результаты проведенных социологических исследований, на сегодня у российской молодежи способность самостоятельно решать свою судьбу, выбирать свою профессиональную деятельность очень слабо сформирована. Кроме того, у молодых людей снижена социальная активность, мотивация к достижению успешного результата, отмечается безынициативность [2, с. 40].

Соответственно, сейчас особую актуальность приобретает проблема создания активной социальной политики, усиления роли социальных институтов в сопровождения профессиональной карьеры, которые должны ответственно подготовить молодежь к работе в жизни в новом социально-экономическом пространстве, где наря- 
ду со специальными профессиональными знаниями и навыками, будут у молодых людей развиваться основные социально-профессиональные качества (осознание особой ценности труда, трудовая мотивация, готовность к труду и созиданию).

Согласно теории взаимосвязи профессионального выбора с генетикой, профессиональный выбор каждой личностью создается и благодаря предрасположенностям. Современные ученые считают, что интеллектуальные способности человека на 50-70\% определяются генетической предрасположенностью.

Генетикам, работающим с генетическим кодом человека, открываются все новые и новые взаимосвязи между человеческими генами и его судьбой. Ученые считают, что интеллектуальные способности на 50-70\% определяются генетической предрасположенностью, а выбор профессии - на 40\%. Возможно выражение, что ребенок, является «продуктом» своей семьи. Ему присущи определенные генетические особенности, переданные от ближайших и далеких предков, что создает физиологические предпосылки к развитию у ребёнка определенных способностей, а, следовательно, предрасположенность к успеху в отдельных видах деятельности. Так в семьях музыкантов, чаще рождаются дети со способностями к музыке, а в семье математиков - к математике, спортсменов - к спорту и т.д.

Всё же вопрос о том, что больше влияет на человека - наследственность или среда, является вопросом, который в течение долгого времени волнует умы историков и писателей, психологов, занимающихся проблемами развития.

Практически любое поведение требует не только врожденных способностей, но и соответствующих условий среды. Главный смысл не в том, что больше влияет на развитие человека - наследственность или воспитание, а в том, каково взаимодействие между собой генов и культуры при формировании индивидуума [1].

Генетический код, или генетический план, существующий в момент зарождения - лишь одна отправная точка развития человека. По такому плану мы наследуем от наших родителей и предков генетически обусловленные физические и поведенческие качества. 
Наша социальная среда, культура - это другая отправная точка развития. Социализация, навыки из нашей культуры, семьи и как это сказывается на нас, зависит от многих факторов, способов и времени их воздействия, и также от людей, вовлеченных в этот процесс.

Способности личности человека зависят от разницы в генах на молекулярном уровне. Существуют три разновидности генов, которые были выявлены учеными: DAT1, DRD2 and DRD4, которые связаны с такими проявлениями, как регуляция внимания, мотивация, жестокость, когнитивные способности, ум. По заключениям ученых, эти гены есть у всех, но существует разница на молекулярном уровне. Дети, у которых была выявлена определенная их разновидность, смогли поступить в ВУЗ, другие - нет. В настоящее время специалисты - генетики указывают на то, что посредством генетических анализов можно определить заложенные природой таланты.

Например, с помощью ДНК-теста возможно определить художественные или музыкальные способности, склонности личности к танцам, спорту, способности к определенному типу школьного обучения.

По мнению специалистов по профориентации, самое важное дать ребенку получить опыт успешного развития в любой области. Чем больше разнообразных возможностей в разных областях вы сможете показать, тем лучше и легче ребёнку станет определиться с выбором специальности, профессии. К примеру, если девочка мечтает о театре, можно и нужно подсказать ей, что в театральной среде возможно быть не только актрисой, но также и драматургом, менеджером по развитию, художником, гримером.

Профессор Сергей Савельев, доктор биологических наук, зав. лабораторией развития нервной системы НИИ морфологии человека РАМН разработал уникальную методику выявления способностей по структурам мозга. Он утверждает, что одарённые люди отличаются от обычных строением мозга. И это мы получаем от родителей и можем только использовать уже имеющиеся особенности мозга. Так, 
если у одного человека центры мозга, управляющие речевым аппаратом в 2,5 раза больше, чем у другого, то и шансы стать хорошим оратором у него выше. Также при отсутствии в мозге выраженных структур, которые отвечают за тонкие согласованные движения рук, глаз, головы, ожидать выдающихся способностей такого человека в качестве художника, ювелира не приходится. Для того чтобы человек был выраженным гением, цепочка способностей должна выпасть сразу, целиком, что является огромной редкостью. С. Савельев утверждает, что развить определённые способности при отсутствии в мозге специализированных областей невозможно. Можно добиться лишь некоторого прогресса в каких-то навыках, если для этого мобилизовать центры мозга, предназначенные для решения других задач, однако это потребует колоссальных усилий.

Однако, стоит отметить, что лишь генной предрасположенности к образованию не достаточно. Дети, выросшие в окружении малообразованных людей, сами не получили хорошего образования, несмотря на гены.

Безусловно установлено, что формирование способностей личности в целом происходит в результате сложного взаимодействия среды и наследственных факторов. Генетики проводят исследование талантливых людей, выявляя их генетические отличия от обычных людей. Пока ученым не всегда удается объяснить выявленные отличия причиной взаимодействия молекул в клетках организма, но на их существование указывают возможные математические вероятности.

\section{Список литературы}

1. Выборнова В.В. Актуализация проблем профессионального самоопределения молодежи // Социологические исследования. 2006. 340 с.

2. Гордиенко Н.В. Конструирование педагогом психологических технологий вхождения в профессиональное пространство как фактор сохранения индивидуальных защитных барьеров личности, предупреждающих профессиональную деформацию / Н.В. Гордиенко // Психологические науки: теория и практика: материалы IV междунар. науч. конф. (г. Москва, ноябрь 2015 г.). М.: Буки-Веди, 2015. С. 39-40. 


\section{References}

1. Vybornova V.V. Aktualizatsiya problem professional'nogo samo-opredeleniya molodezhi // Sotsiologicheskie issledovaniya. 2006. $340 \mathrm{~s}$.

2. Gordienko N.V. Konstruirovanie pedagogom psikhologicheskikh tekhnologiy vkhozhdeniya $\mathrm{v}$ professional'noe prostranstvo kak faktor sokhrane-niya individual'nykh zashchitnykh bar'erov lichnosti, preduprezhdayushchikh pro-fessional'nuyu deformatsiyu / N.V. Gordienko // Psikhologicheskie nauki: teoriya i praktika: materialy IV mezhdunar. nauch. konf. (g. Moskva, noyabr' 2015 g.). M.: Buki-Vedi, 2015. S. 39-40. 